\title{
Microbial activity and bacterial community structure during degradation of microcystins
}

\author{
Kirsten Christoffersen ${ }^{1, *}$, Susanne Lyck ${ }^{1}$, Anne Winding ${ }^{2}$ \\ ${ }^{1}$ Freshwater Biological Laboratory, University of Copenhagen, 3400 Hillerød, Denmark \\ ${ }^{2}$ Department of Microbial Ecology and Biotechnology, National Environmental Research Institute, 4000 Roskilde, Denmark
}

\begin{abstract}
Degradation of realistic microcystin concentrations in lake water with indigenous bacteria was studied in laboratory and field experiments following inoculation with lysed toxic algal material containing microcystin primarily from Microcystis sp. or purified commercial microcystin-LR to microcosms. It was hypothesised that the bacterial community from a lake with frequent occurrence of toxic cyanobacteria can degrade microcystin along with other organic compounds. The initial dissolved microcystin concentrations ranged between 10 and $136 \mathrm{\mu g} \mathrm{l}^{-1}$ (microcystin-LR equivalents) in the laboratory experiment, using toxic natural algal material from 3 lakes and purified microcystin-LR, and between 2 and $54 \mathrm{\mu g} \mathrm{l}^{-1}$ in the field experiment, using toxic natural algal material and material from a highly toxic culture. Lysed material from a non-toxic algal culture (Scenedesmus sp.) was included in the latter experiment to evaluate the effects of organic lysates on bacterial proliferation in the absence of microcystin. An exponential decline of the dissolved toxins was observed in all cases with toxins present, and the degradation rates ranged between 0.5 and $1.0 \mathrm{~d}^{-1}$. No lag phases were observed but slow initial degradation rates occurred in 2 out of 7 cases. Microcystin was almost eliminated from the water after around $8 \mathrm{~d}$. Results from concomitant measurements of bacterial abundance and net production showed an elevated bacterial activity within 1 to $2 \mathrm{~d}$ after the inoculation with algal lysates including microcystins, and this resulted in a net accumulation of bacterial cells. The heterotrophic nanoflagellates responded quickly to the bacterial growth and probably consumed a considerable amount of the bacteria. The microbial activities returned to initial values within 5 to $6 \mathrm{~d}$ as the toxins and other dissolved organic substrates (measured as dissolved organic carbon [DOC]) were degraded. The degradation of DOC correlated with the degradation of microcystin, which suggests that these processes are coupled. The diversities of the bacterial communities from the laboratory and field microcosm experiments were analysed by polymerase chain reaction-density gradient gel electrophoresis (PCR-DGGE) of 16S rDNA, which showed that the indigenous bacterial community responded quickly to the addition of lysates. Our study confirms that bacteria can efficiently degrade microcystins in natural waters with previous cyanobacterial histories and that the degradation process can run quickly and without lag phases.
\end{abstract}

KEY WORDS: Microcystins $\cdot$ Degradation rates $\cdot$ Bacteria $\cdot$ Community structure $\cdot 16 \mathrm{~S}$ rDNA

\section{INTRODUCTION}

Cyanobacteria exist under a variety of climatic, nutrient and physic conditions, and are likely to form blooms (here defined as visible occurrence of 1 or several dominating cyanobacterial species). This distinct group of bacteria is photosynthetic and produce several metabolites that include a number of endotoxins,

*E-mail: kchristoffersen@zi.ku.dk of which hepatotoxins are commonly found in mass occurrences of cyanobacteria, especially under eutrophic conditions (Carmichael 1992, Skulberg et al. 1994). The toxicity of these hepatotoxins to wildlife and humans is an unquestionable fact (Falconer 1993).

Toxic cyanobacteria release their toxins to the surrounding water after a momentary collapse caused by unfavourable growth conditions (Berg et al. 1987), by disintegrating over longer times (M. F. Watanabe et al. 1992, M. M. Watanabe et al. 1992) or by lysis following 
algicide treatments to remove nuisance algae (Jones \& Orr 1994). The toxins, however, end up in a dissolved form in the water phase irrespective of the mode of lysis. Since many organisms from amoeba to humans are exposed to surface waters during their life span, knowledge about the fate of the dissolved toxins in aquatic systems is essential.

Microcystin is a well-studied cyanobacterial toxin. It is a cyclic peptide with a molecular weight of 1000 and has proved to be a very stable molecule. The general structure of microcystins is cyclo-(D-Ala ${ }^{1}-\mathrm{X}^{2}-\mathrm{D}$ MeAsp ${ }^{3}-Z^{4}-$ Adda $\left.^{5}-D-G_{l}{ }^{6}-M_{d h a}{ }^{7}\right)$, where $\mathrm{X}$ and $\mathrm{Y}$ are variable L-amino acids (Carmichael 1992). Microcystins tolerate heating up to $100^{\circ} \mathrm{C}$, chlorination and other treatments used for removal of unwanted compounds, e.g. in waste water (Nicholson et al. 1994, Lam \& Prepas 1997, Robertson et al. 1998, Feitz et al. 1999, Lawton et al. 1999). High concentrations of dissolved microcystin in situ are exceptions as reported by Jones \& Orr (1994), who found 1.3 to $1.8 \mathrm{mg}$ microcystins $\mathrm{l}^{-1}$ after addition of a biocide to remove a highly toxic cyanobacterial bloom from a drinking water site in Australia. Generally, only moderate microcystin concentrations (a few micrograms per litre of water) have been recorded at natural sites such as those recorded by Christoffersen (1996) of up to $0.14 \mathrm{mg}$ microcystins $\mathrm{l}^{-1}$ from Danish lakes and even lower values in a seasonal study in a Finish lake by Lahti et al. (1997). Since there are few routine monitoring programmes of dissolved toxins in drinking water or recreational waters due to technical and economical constraints, it remains unclear whether these values are representative.

If it is assumed that the lack of detectable dissolved microcystin is not just a consequence of dilution, it must either be degraded rather quickly in the water column by microbes that can utilise similar organic substrates (e.g. Jones \& Orr 1994) or adsorb to particles in the water, the sediment or both (Lahti et al. 1997, Morris et al. 2000). Binding to detritus seems to account for a minor removal of microcystin from the water phase (Lahti et al. 1997). Adsorption to inert particles (clay, coal, etc.) seems effective (Donati et al. 1994, Lambert al. 1996, Morris et al. 2000) but is not likely to happen in natural sites due to lack of such particles in sufficient densities.

Degradation of dissolved microcystin from temperate lakes has been studied in several cases. Rapala et al. (1994) monitored microcystin-LR after exposure to inocula of natural populations of heterotrophic bacteria from the water phase and from sediments from several lakes. Microcystin-LR was degraded over a $30 \mathrm{~d}$ period and more rapidly if the inocula were from locations with a history of cyanobacterial blooms. Kiviranta et al. (1991) and M. F. Watanabe et al. (1992) found that microcystin-
RR was not degraded during a long-term study (months). Recently, half-lives of 3 to $9 \mathrm{~d}$ have been reported (Jones \& Orr 1994, Lam et al. 1995, Cousins et al. 1996), and several bacterial strains involved in the degradation have been identified (Jones et al. 1994, Bourne et al. 1996, Takenaka \& Watanabe 1997).

Despite differences in the experimental conditions (type of inoculum, temperature, etc.) the above observations indicate that microcystins that are deliberately (e.g. through water management) or naturally released to the water column undergo a biotransformation mediated by heterotrophic bacteria. For risk assessment purposes it is important to know how fast the process is operating, how long a lag phase is before the degradation and how important other components of biotic origin, such as the dissolved carbon pools, are. Finally, it is of relevance to know whether all of the microcystin can be eliminated from the water column and how long this would take. As a starting point we hypothesised that the bacterial community from a lake where cyanobacteria are common can degrade microcystin along with other organic compounds frequently found in their environment. We also expected that a high and diverse pool of dissolved (labile) organic substances would stimulate the proliferation of specific bacterial strains and that microcystin would eventually be removed from the water column by such bacteria. Therefore, the bacterial community must include strains capable of degrading specific compounds or commonly found strains must posses this ability and just need to activate the enzymatic apparatus. In this study we followed the degradation of microcystins from toxic cyanobacterial blooms, produced in various locations, by a bacterial community from 1 location where cyanobacteria are common. Changes in the degrading bacterial communities were followed by a nucleic acid technique.

\section{MATERIALS AND METHODS}

Laboratory experiment. A 51 water sample from the eutrophic Frederiksborg Slotssø was collected on 2 July 1996 and immediately pre-filtered through $20 \mu \mathrm{m}$ net followed by filtration through GF/C filters (Whatman). The filtration procedure removed large protozoans and all zooplankton but left heterotrophic bacteria and small protozoans in the filtered water. The batch was divided into 15 acid-washed $250 \mathrm{ml}$ bottles. Lysed algal material $(2 \mathrm{ml}$ ) was added to each of 3 sets of 3 bottles (see below and Table 1), 3 bottles contained purified microcystin-LR (Sigma) and the re-maining 3 bottles did not receive any additional material (controls). The initial microbial communities in all bottles were representative of the bacterial community in 
Frederiksborg Slotssø. A subsample of $15 \mathrm{ml}$ was removed from each bottle within $1 \mathrm{~h}$ of the start for determination of dissolved toxins, particulate (POC) and dissolved organic carbon (DOC), bacterial abundance and production, and heterotrophic nanoflagellate (HNF) abundance. Finally, the bottles were wrapped in aluminium foil, mounted on a rotation wheel (approx. $1 \mathrm{rpm}$ ) and incubated at $20^{\circ} \mathrm{C}$. The bottles were further subsampled for dissolved toxins, bacterial abundance and production, and HNF abundance after 1, 2, 5 and $8 \mathrm{~d}$. Bacterial community structures were analysed after 1 (controls), 8 and $19 \mathrm{~d}$ (all bottles) from $15 \mathrm{ml}$ of culture removed from each bottle. The experiment ended after $21 \mathrm{~d}$. At this point, samples for determination of particulate and dissolved toxins as well as particulate and dissolved carbon were taken from all bottles.

The algal materials used in the laboratory experiment originated from concentrated (by $20 \mu \mathrm{m}$ sieving) and freeze-dried natural cyanobacterial communities collected from 3 Danish lakes during August 1994. The sample location, the dominating cyanobacterial strain(s) and the microcystin content based on previous HPLC measurements (following Lyck et al. 1996) are given in Table 1. The extracts contained a mixture of microcystin-LR and -RR according to HPLC analyses using purified material form commercial stocks (Sigma).

The freeze-dried materials were re-hydrated in deionized, purified water during sonication (Bransonic 2210 ) at $50000 \mathrm{~Hz}$ for $2 \times 30 \mathrm{~min}$ separated by a $30 \mathrm{~min}$ rest period. The extracts were filtered through GF/C filters to remove cell debris and subsequently diluted to obtain the desired microcystin concentration applied in laboratory experiments. No attempts were made to purify the toxin extract further or to remove the nontoxic organic matter associated with the extracts. All cyanobacteria and heterotrophic bacteria were expected to lyse during this treatment.

Table 1. Characteristic of the materials added to the laboratory and field microcosms. DW: dry weight

\begin{tabular}{|lcl|}
\hline Origin of test material & $\begin{array}{c}\text { Toxin content } \\
\left(\mathrm{mg} \mathrm{g}^{-1} \mathrm{DW}\right)\end{array}$ & \multicolumn{1}{c|}{$\begin{array}{c}\text { Cyanobacterial } \\
\text { strain(s) }\end{array}$} \\
\hline Laboratory experiment & & \\
Microcystin-LR (commercial) & Stock & $\begin{array}{l}\text { Microcystis aeruginosa } \\
\text { Bryrup Langs }\end{array}$ \\
Kulsø & 2.79 & $\begin{array}{l}\text { Microcystis sp., Anabaena sp. } \\
\text { Frederiksborg Slotss } \varnothing\end{array}$ \\
$\begin{array}{l}\text { Field experiment } \\
\text { Microcystis culture }\end{array}$ & 0.35 & Microcystis sp. \\
Mixed lake bloom & 2.00 & M. aeruginosa CYA228 \\
Scenedesmus culture & 0.35 & M. aeruginosa, M. wessenbergii \\
& 0.00 & None \\
\hline
\end{tabular}

Field experiment. Six transparent microcosms (i.e. enclosures) were established in the eutrophic Frederiksborg Slotssø in September 1997 and used to simulate the degradation patterns of collapsed algal bloom material. The enclosures were made of $0.1 \mathrm{~mm}$ polyethylene, and $75 \mathrm{l}$ of lake water from $3 \mathrm{~m}$ depths was pumped into each. The conductivity of the water was $423 \mu \mathrm{S} \mathrm{cm}{ }^{-1}$ and the temperature was $21.5^{\circ} \mathrm{C}$. The water contained indigenous cyanobacterial colonies, zooplankton and a microbial community of bacteria, protozoans and small phytoplankton species. The enclosures were attached to a floating frame that was anchored approx. $50 \mathrm{~m}$ from the shoreline at a water depth of $3 \mathrm{~m}$. Three types of lysed algal materials (see below and Table 1) were used as homologues for collapsed blooms. The bloom material originated from (1) a dense laboratory culture of a highly toxic Microcystis aeruginosa (Kützing) Lemmermann CYA 228/1 (2 mg microcystin-RR $^{-1}$ dry weight [DW] of algal material), (2) a concentrated toxic cyanobacterial lake community from Frederiksborg Slotssø dominated (98\% of total cell volume) by several Microcystis sp. (approx. $0.3 \mathrm{mg}$ microcystin-LR g ${ }^{-1} \mathrm{DW}$ of algal material) and (3) a dense laboratory culture of Scenedesmus quadricauda (Breb). The laboratory cultures were harvested by centrifugation at $1500 \times g$ for $15 \mathrm{~min}$, while the lake assemblage was obtained after filtration onto a $20 \mu \mathrm{m}$ mesh. The concentrated material was dissolved in $500 \mathrm{ml} \mathrm{GF} / \mathrm{C}$ filtered lake water and heated to $70^{\circ} \mathrm{C}$ for $30 \mathrm{~min}$ to lyse the cyanobacterial cells and inactivate associated bacteria. Subsamples of $5 \mathrm{ml}$ of each solution were taken for later determination of the initial toxin content. The solutions containing dissolved and particulate material were added directly to duplicate enclosures so that the additions were identical in terms of organic particulate material. The water in the enclosures was mixed thoroughly before sampling. Water samples were taken 8 times during the following $8 \mathrm{~d}$, with the most intensive sampling (5 times) during the first $2 \mathrm{~d}$. Bacterial communities were analysed after $0,0.8$ and $2.9 \mathrm{~d}$ by polymerase chain reaction-density gradient gel electrophoresis (PCR-DGGE; see below for details). Integrated water samples were brought to the laboratory within 30 min and further subsampled for analysis of dissolved and particulate microcystin content, particulate and dissolved carbon, abundance, net production and diversity of bacteria, and abundance of HNF (see below for details). Each sampling occasion included in situ measurements of temperature, oxygen and $\mathrm{pH}$ by a multiprobe (Yellow Springs Instruments). 
Toxin analysis. Subsamples for the determination of dissolved toxins in raw water were obtained by gentle filtration of $10 \mathrm{ml}$ water samples through GF/F filters using low vacuum $(<20 \mathrm{~cm} \mathrm{Hg})$. Microcystins were quantified after dilution with deionized, purified water by an enzyme-linked immunosorbent assay (ELISA; Millipore) based on polyclonal antibodies against microcystin (Chu et al. 1989). Each sample was analysed in duplicate following the procedures described in Thostrup \& Christoffersen (1999).

In the field experiment, particulate-bound microcystins from the enclosures and the lake (the first sampling date) were measured from 100 to $250 \mathrm{ml}$ of water filtered through pre-combusted and pre-weighed $\mathrm{GF} / \mathrm{C}$ filters. The filters were freeze dried, weighed to obtain the amount of material and stored at $-20^{\circ} \mathrm{C}$ until further treatments. Before analysis the filters were soaked in $10 \mathrm{ml}$ deionized, purified water and treated with sonication for $30 \mathrm{~min}$ to disrupt the cells. The extracts were finally filtered through $0.45 \mu \mathrm{m}$ cellulose nitrate filters and diluted 50 to 500 times before quantification of microcystin by ELISA as described above. All initial particulate microcystin concentrations were furthermore analysed by HPLC as described in Lyck (in press) to obtain an independent measurement and to identify the microcystin variants.

Microbial abundance and activity. The abundance of bacteria and heterotrophic flagellates was determined from subsamples fixed with glutaraldehyde (1.5\% final concentration) and stained with 4',6-diamidino-2phenylindole (DAPI; $0.5 \mu \mathrm{g} \mathrm{ml}^{-1}$ final concentration) for 10 min before filtration onto $0.2 \mu \mathrm{m}$ (bacteria) or $0.8 \mu \mathrm{m}$ (flagellates) black polycarbonate filters (Poretics). The filters were rinsed with $0.2 \mu \mathrm{m}$ filtered distilled water and mounted on glass slides with non-fluorescent immersion oil before counting. The slides were kept frozen at $-20^{\circ} \mathrm{C}$ until microscopical analyses were done. The filters were inspected under an Olympus BH2 microscope, equipped with an ultraviolet and blue filter set with excitation and emission wavelengths of 365 and $390 \mathrm{~nm}$, at $1250 \times$ magnification.

Bacterial net production was measured from ${ }^{3} \mathrm{H}$ thymidine (Amersham) incorporation into DNA during 20 min followed by ice-cold trichloroacetic extraction as described by Fuhrman \& Azam (1980). An average conversion factor of $2 \times 10^{18}$ cells mol $^{-1}$ of incorporated thymidine was applied (Smits \& Riemann 1988).

Bacterial DNA. For analysis of bacterial DNA, $15 \mathrm{ml}$ of water was filtered onto $0.2 \mu \mathrm{m}$ Gelman Supor 200 filters (Gelman Sciences), and the filters were rinsed with 3 times $3 \mathrm{ml}$ Tris-EDTA (TE) buffer (pH 7.5) (Sambrook et al. 1989) before storage of the filters, initially at $-20^{\circ} \mathrm{C}$, later at $-80^{\circ} \mathrm{C}$.

Bacterial DNA was extracted onto one-fourth of each filter that again was cut into small pieces and sepa- rated into 2 parts. One part was incubated on ice with $1 \mathrm{ml}$ of acetone in a $1.5 \mathrm{ml}$ Eppendorf tube for $5 \mathrm{~min}$ followed by centrifugation to disrupt bacterial spores. After the pellet was dried in a vacuum centrifuge, the other part of the filter was added with $100 \mu \mathrm{l}$ TE buffer with $10 \mathrm{mg} \mathrm{ml}^{-1}$ lysozyme (Sigma L6876) and incubated for $1 \mathrm{~h}$ at $37^{\circ} \mathrm{C}$ (Riemann \& Winding 2001). Then $500 \mu \mathrm{l}$ of $6 \mathrm{M}$ guadine thiocyanate in TE buffer was added, and the mixture was incubated for $5 \mathrm{~min}$ at $102^{\circ} \mathrm{C}$, followed by addition of $1.2 \mathrm{ml}$ of $6 \mathrm{M} \mathrm{NaI}$ in TE buffer, and incubated for $20 \mathrm{~min}$ at room temperature. Particulate matter was pelleted and $10 \mu \mathrm{l}$ QiaexII suspension (Qiagen) was added to the supernatant. To ensure efficient binding of DNA to the QiaexII particles, the tube was gently turned over every 2 min for 10 min (which kept the particles in suspension), followed by centrifugation and removal of the supernatant. The QiaexII particles with the DNA were washed twice with a mixture of $2 \mathrm{M}$ guadine thiocyanate and $4 \mathrm{M} \mathrm{NaI}$ in TE buffer, followed by 3 washes with $80 \%$ ethanol, with centrifugation steps in between. After air drying, the QiaexII particles were re-suspended in $50 \mu \mathrm{l} \mathrm{TE}$ buffer and heated at $50^{\circ} \mathrm{C}$ for $10 \mathrm{~min}$ to release DNA from the particles. After centrifugation, the supernatant containing the extracted DNA was stored at $4^{\circ} \mathrm{C}$ for 2 to $5 \mathrm{~d}$ before PCR. All centrifugations were at $15000 \times g$ for $3 \mathrm{~min}$ at $4^{\circ} \mathrm{C}$.

A fragment of bacterial 16S rDNA (position 968 to 1378 by Escherichia coli numbering) was PCR amplified by the use of the primer sets F984GC (5'-[GC clamp]-AAC GCG AAG AAC CTT AC-3') (Heuer et al. 1997) and R1378 (5'-CGG TGT GTA CAA GAC CC-3' (Heuer et al. 1998) spanning the V6 to V8 region of Eubacteria. The GC-clamp (5'-CGCCCGGGGCGCGCCCCGGGCGGGGCG-GGGGCACGGGGGG-3') was from Heuer et al. (1997). The primers were obtained from DNA Technology. The PCR reactions were performed in a Perkin-Elmer GeneAmp PCR System 9600 in $25 \mu \mathrm{l}$ reaction mixtures containing $0.25 \mathrm{U}$ of Taq polymerase Stoffel fragment (Perkin-Elmer), each deoxynucleotide triphosphate (dNTP) at a concentration of $0.2 \mathrm{mM}$, $3.75 \mathrm{mM} \mathrm{MgCl}_{2}$ and $2 \mu \mathrm{M}$ of each primer, all in Stoffel PCR buffer (Perkin-Elmer). The PCR amplification was as follows: an initial denaturation step $\left(94^{\circ} \mathrm{C}\right.$ for $\left.5 \mathrm{~min}\right)$, 30 cycles of $1 \mathrm{~min}$ of denaturation at $95^{\circ} \mathrm{C}, 1 \mathrm{~min}$ of primer annealing at $53^{\circ} \mathrm{C}$ and 2 min of primer extension at $72^{\circ} \mathrm{C}$, and finally $10 \mathrm{~min}$ of primer extension at $72^{\circ} \mathrm{C}$. The yield of the PCR reaction and the size of the products were analysed on a $1 \%$ agarose gel.

The PCR products were separated by DGGE as described by Heuer et al. (1997) using a D GENE System (Bio-Rad) for casting the gel and running the DGGE. A denaturing gradient of 40 to $60 \%$ was applied, and $7 \mu \mathrm{l}$ of each PCR product was loaded. The gel was silver stained according to Heuer et al. (1997), 
mounted with support film underneath and a cellophane sheet on top (Kem-En-Tech), dried overnight at $50^{\circ} \mathrm{C}$, photographed with a Hamamatsu chilled charge coupled device (CCD) C5985 camera and digitalized with the corresponding software (Hamamatsu HPD-CP extended version 2.1.2, Photonics). The number of bands and their position on the density gradient gel electrophoresis (DGGE) gel were analysed and dendrograms were created based on the Dice coefficient of similarity and the unweighted pair-group method using arithmetic average (UPGMA) method by Dendron $^{\circledR}$ (Solltech).

POC and DOC analysis. Concentrations of DOC and POC were measured from $5 \mathrm{ml}$ subsamples filtered through pre-combusted $13 \mathrm{~mm}$ GF/F filters. The material retained on the filters (POC) was dried for $3 \mathrm{~h}$ at $60^{\circ} \mathrm{C}$ and combusted at $600^{\circ} \mathrm{C}$ in a quartz tube furnace, and the $\mathrm{CO}_{2}$ was measured in an infrared gas analyser (ADC $22 \mathrm{MK}$ ). The dissolved material passing through the filters (DOC) was collected in pre-combusted glass vials, acidified with 1 drop of $2 \mathrm{~N} \mathrm{HCl}$ and then purged with nitrogen gas to remove inorganic carbon. DOC concentrations were measured by the dry combustion method using a Shimadzu TOC-5000.

\section{RESULTS}

\section{Laboratory experiment}

The initial microcystin concentrations ranged between 10 and $136 \mu \mathrm{g}$ microcystins $\mathrm{l}^{-1}$ in the cultures and declined in an exponential manner with time (Fig. 1). The disappearance of microcystins from all 4 sources (3 different extracts of bloom material and purified microcystin-LR) commenced without any lag phase. In one case an initial slow rate was observed

Table 2. Disappearance rates (mean \pm standard deviation) of microcystin in laboratory and field bacterial cultures with added lyophilised algal material. ${ }^{*} \mathrm{p}>0.01{ }^{*}{ }^{* *} \mathrm{p}<0.001$. ns: not significant at $\mathrm{p}>0.05$

\begin{tabular}{|lclr|}
\hline & $\begin{array}{c}\text { Disappearance } \\
\text { rate }\left(\mathrm{d}^{-1}\right)\end{array}$ & $\begin{array}{c}\text { Coefficient } \\
\left(\mathrm{r}^{2}\right)\end{array}$ & $\mathrm{n}$ \\
\hline Laboratory experiment & & & \\
Microcystin-LR & $0.763 \pm 0.058$ & $0.931^{* *}$ & 15 \\
Bryrup Langs & $0.793 \pm 0.080$ & $0.884^{* *}$ & 15 \\
Kulsø & $0.518 \pm 0.060$ & $0.853^{* *}$ & 15 \\
Frederiksborg Slotss $\varnothing$ & $0.485 \pm 0.028$ & $0.957^{* *}$ & 15 \\
Field experiment & & & \\
Microcystis culture & $1.057 \pm 0.172$ & $0.729^{* *}$ & 14 \\
Mixed lake bloom & $0.651 \pm 0.140$ & $0.607^{*}$ & 14 \\
$\begin{array}{l}\text { Scenedesmus culture } \\
\text { a }\end{array}$ & $0.117 \pm 0.078$ & $0.274(\mathrm{~ns})$ & 8 \\
\hline
\end{tabular}

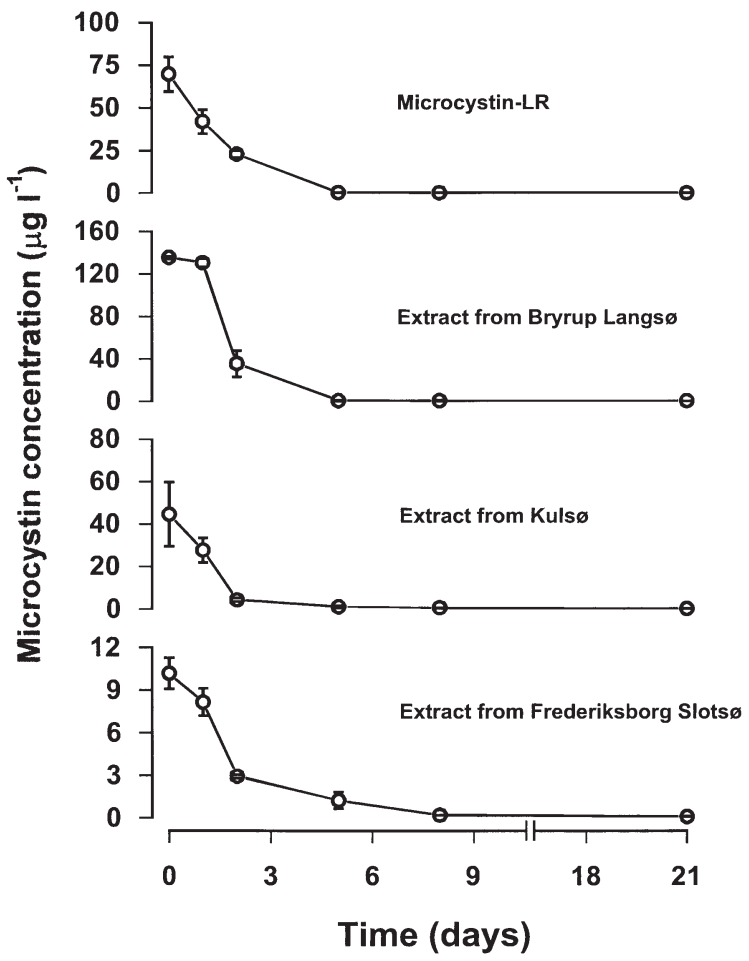

Fig. 1. Concentration of dissolved microcystin-LR equivalents in laboratory cultures as a function of time after addition of lysed bloom material and purified microcystin to lake water. Each point represents the average of 3 replicate samples; error bars are \pm 1 standard deviation of the mean

(algal material from Bryrup Langsø) but it did not affect the preceding period.

The disappearance rates were estimated from linear regression of log-transformed microcystin concentration versus time during the first $8 \mathrm{~d}$. The rates ranged from 0.485 to $0.793 \mathrm{~d}^{-1}$ (Table 2) and seemed to increase linearly with the initial microcystin concentrations, although not significantly $\left(\mathrm{r}^{2}=0.767, \mathrm{p}=0.124\right)$. No relationship between the disappearance rates and the initial concentration of DOC (Table 3) was found. The time required to reach a level of $1 \mu \mathrm{g}$ microcystin $\mathrm{l}^{-1}$ (the World Health Organization [WHO] recommended maximal concentration in drinking water) was 5 to $7 \mathrm{~d}$ as calculated from the disappearance equations. The microcystins were still present after $8 \mathrm{~d}$ but in very low quantities ( $<2 \%$ of the initial amount) and were not detectable after $21 \mathrm{~d}$ (Fig. 1).

Bacterial abundances increased 3.6 to 6.5 times during the first $24 \mathrm{~h}$ in the cultures with added lysed algal material and less (1.3 to 2.6 times) in the control cultures and cultures with added pure microcystin-LR (Fig. 2a). A marked increase in bacterial production was observed in the cultures with added lysed algal material during the first $2 \mathrm{~d}$ but not in the control culture or in those with purified microcystin-LR (Fig. 2b). 
Table 3. Start and final concentrations of dissolved (DOC) and particulate organic carbon (POC) in the cultures. Values are means of 3 replicates for the laboratory experiment and of 2 replicates for the field experiment. Means are \pm standard deviation (laboratory experiment) or total deviation (field experiment)

\begin{tabular}{|lcccc|}
\hline & \multicolumn{2}{c}{ DOC $\left(\mathrm{mg} \mathrm{l}^{-1}\right)$} & \multicolumn{2}{c|}{ POC $\left(\mathrm{mg} \mathrm{l}^{-1}\right)$} \\
& Start & Final & Start & Final \\
\hline Laboratory experiment & & & & \\
Microcystin-LR & $5.7 \pm 0.3$ & $5.3 \pm 0.3$ & $1.10 \pm 0.07$ & $0.89 \pm 0.09$ \\
Bryrup Langsø & $9.0 \pm 0.2$ & $5.7 \pm 0.1$ & $1.13 \pm 0.01$ & $0.97 \pm 0.07$ \\
Kulsø & $7.3 \pm 0.3$ & $5.4 \pm 0.3$ & $1.67 \pm 0.02$ & $1.12 \pm 0.01$ \\
Frederiksborg Slotssø & $8.1 \pm 0.02$ & $5.7 \pm 0.4$ & $1.53 \pm 0.03$ & $1.18 \pm 0.09$ \\
Control & $5.8 \pm 0.4$ & $5.6 \pm 0.3$ & $1.34 \pm 0.24$ & $0.96 \pm 0.10$ \\
Field experiment & & & & \\
Microcystis sp. culture & $14.1 \pm 0.9$ & $5.0 \pm 0.2$ & $17.2 \pm 0.9$ & $11.7 \pm 0.6$ \\
Mixed lake bloom & $14.7 \pm 1.82$ & $3.7 \pm 1.5$ & $14.6 \pm 0.3$ & $11.6 \pm 2.2$ \\
Scenedesmus sp. culture & $7.2 \pm 3.5$ & $5.2 \pm 0.2$ & $17.9 \pm 1.9$ & $12.3 \pm 0.9$ \\
& & & & \\
\hline
\end{tabular}

These DOC reductions can be explained by the measured bacterial gross production integrated over the time, if it is assumed that the measured net production can be extrapolated on a $24 \mathrm{~h}$ basis and that the bacterial growth efficiency is $50 \%$. The biovolume of the lake bacteria used in this study is between 0.35 and $0.6 \mu^{3}$ (unpubl.), and the carbon content is

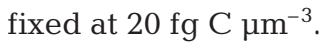

The analysis of the genetic diversity of the bacterial communities by $16 \mathrm{~S}$ rDNA PCR-DGGE showed an increase in the diversity from 14 to 16 bands at the beginning of the experiment to a maximum of 32 bands after $19 \mathrm{~d}$ in the samples with microcystinLR added (Table 4). The number of

The elevated bacterial activities during the first few days were associated with the initial high concentrations of DOC in the cultures with lysed algal material (Table 3). Bacterial abundances remained at approx. 2 times the initial values, i.e. at $6 \times 10^{6}$ to $8 \times 10^{6}$ cells $\mathrm{ml}^{-1}$ in all cultures, until the end of the experiment, while the bacterial production returned to initial values.

The DOC pools in the cultures with algal material were initially 7.3 to $9.0 \mathrm{mg} \mathrm{l}^{-1}$ but were reduced by 30 to $37 \%$ of the initial pool during the experiment, while the pools in the cultures with pure microcystin and the control cultures were lower (around $5.8 \mathrm{mg} \mathrm{l}^{-1}$ ) and were reduced by only 3 to $7 \%$. The POC pools varied less between the cultures ( 1.1 to $1.7 \mathrm{mg} \mathrm{l}^{-1}$ ) and were reduced by 14 to $37 \%$ of the initial level (Table 3).

Table 4. Number of bands detected by polymerase chain reaction density gradient gel electrophoresis PCR (DGGE). Numbers are from replicate bottles or microcosms. ND: no data

\begin{tabular}{|lccc|}
\hline Laboratory experiment & & & \\
Samples & Day 1 & Day 8 & Day 19 \\
\hline Frederiksborg Slotss $\varnothing$ & ND & $18 / 18$ & $20 / 19$ \\
Bryrup Langsø & ND & $19 / 20$ & $22 / 20$ \\
Kulsø & ND & $23 / 21$ & $24 / 24$ \\
Microcystin-LR & ND & $25 / 24$ & $32 / 32$ \\
Control & $14 / 16$ & $19 / 19$ & $28 / 28$ \\
& & & \\
Field experiment & & & \\
Samples & Day 0 & Day 0.8 & Day 2.9 \\
\hline Microcystis sp. culture & $12 / 12$ & $19 / 18$ & $12 / 14$ \\
Mixed lake bloom & $12 / 14$ & $18 / 18$ & $16 / 16$ \\
Scenedesmus sp. culture & $19 / 19$ & $21 / 24$ & $22 / 21$ \\
\hline
\end{tabular}

bands increased to 19 to 24 in the cultures with lysed algal material during the same period. A total of 48 band positions was identified; of these, 2 bands were common to all cultures and 1 band was found in all cultures except the controls at Day 1. All cultures had a similarity index above $48 \%$, and the deepest branching separated the control culture at Day 1 from all other samples (Fig. 3a). Control cultures and cultures with added pure microcystin were separated from the cultures with added lysed algal material. The latter observed separation compares with the relative low bacterial abundance and net production (Fig. 2a,b) and the smallest decrease in DOC concentration (Table 3). The cultures with lysed algal material clustered together, except Kulsø samples after Day 19, and were also characterized by higher bacterial abundances, increased bacterial net production and, thus, greater degradation of DOC.

Increases in the population densities of HNF followed the increases in bacterial abundances (Fig. 2c). Very few HNF were present at the start (on average $315 \mathrm{HNF} \mathrm{ml}^{-1}$ ) of the experiment due to the initial $\mathrm{GF} / \mathrm{C}$ filtration of the water but a re-growth resulted in $0.16 \times 10^{5}$ to $1.97 \times 10^{5}$ cells ml ${ }^{-1}$ within $5 \mathrm{~d}$. The lowest increases were found in the controls $\left(0.25 \times 10^{5}\right.$ cells $\mathrm{ml}^{-1}$ ) and cultures with added purified microcystin $\left(0.16 \times 10^{5}\right.$ cells $\left.\mathrm{ml}^{-1}\right)$.

\section{Field experiment}

The temperature decreased gradually from $21.5^{\circ} \mathrm{C}$ to $18^{\circ} \mathrm{C}$ during the first $6 \mathrm{~d}$ and decreased further to $15.5^{\circ} \mathrm{C}$ towards the end of the experiment. Oxygen saturations varied around $110 \%$ in all enclosures at the start and decreased to approx. $100 \%$ in the enclosures 
with Scenedesmus sp. and lake bloom material during the rest of the period. Oxygen was lower (50 to $67 \%$ ) in the enclosures with lysed Microcystis sp. culture than in the other enclosures between Days 1 and 4 but increased after that to $75 \%$.

The average concentration of dissolved microcystin was initially $54 \mathrm{\mu g} \mathrm{l}^{-1}$ in the treatments with a lysed Microcystis sp. culture and $2.3 \mu \mathrm{g} \mathrm{l}^{-1}$ in the treatments with lake bloom material culture (Fig. 4). The dissolved microcystin content declined rapidly in both cases but with an initial slow rate during approx. $24 \mathrm{~h}$ for the lake bloom material. Disappearance rates of microcystin were estimated from linear regression of logtransformed microcystin concentration versus time during $8 \mathrm{~d}$ and were 1.057 and $0.651 \mathrm{~d}^{-1}$ for the Microcystis sp. culture and the lake material, respectively (Table 2). Dissolved microcystins were barely detectable on the last sampling occasion, i.e. $8 \mathrm{~d}$ after amendment, and the times to achieve the WHO guideline $\left(1 \mu \mathrm{g}\right.$ microcystin $\left.\mathrm{l}^{-1}\right)$ were 3.8 and $1.3 \mathrm{~d}$ for cultured Microcystis sp. and lake material, respectively. Dissolved microcystins were also found in the treatments with lysed Scenedesmus sp. culture (Fig. 4c) and originated from the natural lake cyanobacteria that were present in the natural but $20 \mu \mathrm{m}$ filtered water used to fill the enclosures as no toxic material was added. No significant changes in the microcystin concentration were detected (Table 2). A particulate fraction containing mainly microcystin-RR of approx. $1 \mathrm{\mu g} \mathrm{l}^{-1}$ (detected by HPLC analysis) was also present in all enclosures (Fig. 4) and originated from the naturally occurring cyanobacteria, i.e. the lake algal community and detritus pools.

The POC concentrations were 15 to $18 \mathrm{mg} \mathrm{l}^{-1}$ while the DOC concentrations were around $14 \mathrm{mg} \mathrm{l}^{-1}$ after the addition of crude extracts of cultured Microcystis sp. or lake bloom material, but only $5 \mathrm{mg}$ $\mathrm{l}^{-1}$ after addition of a Scenedesmus sp. culture. Both fractions were reduced substantially, except in the enclosures with Scenedesmus sp., during the ex-
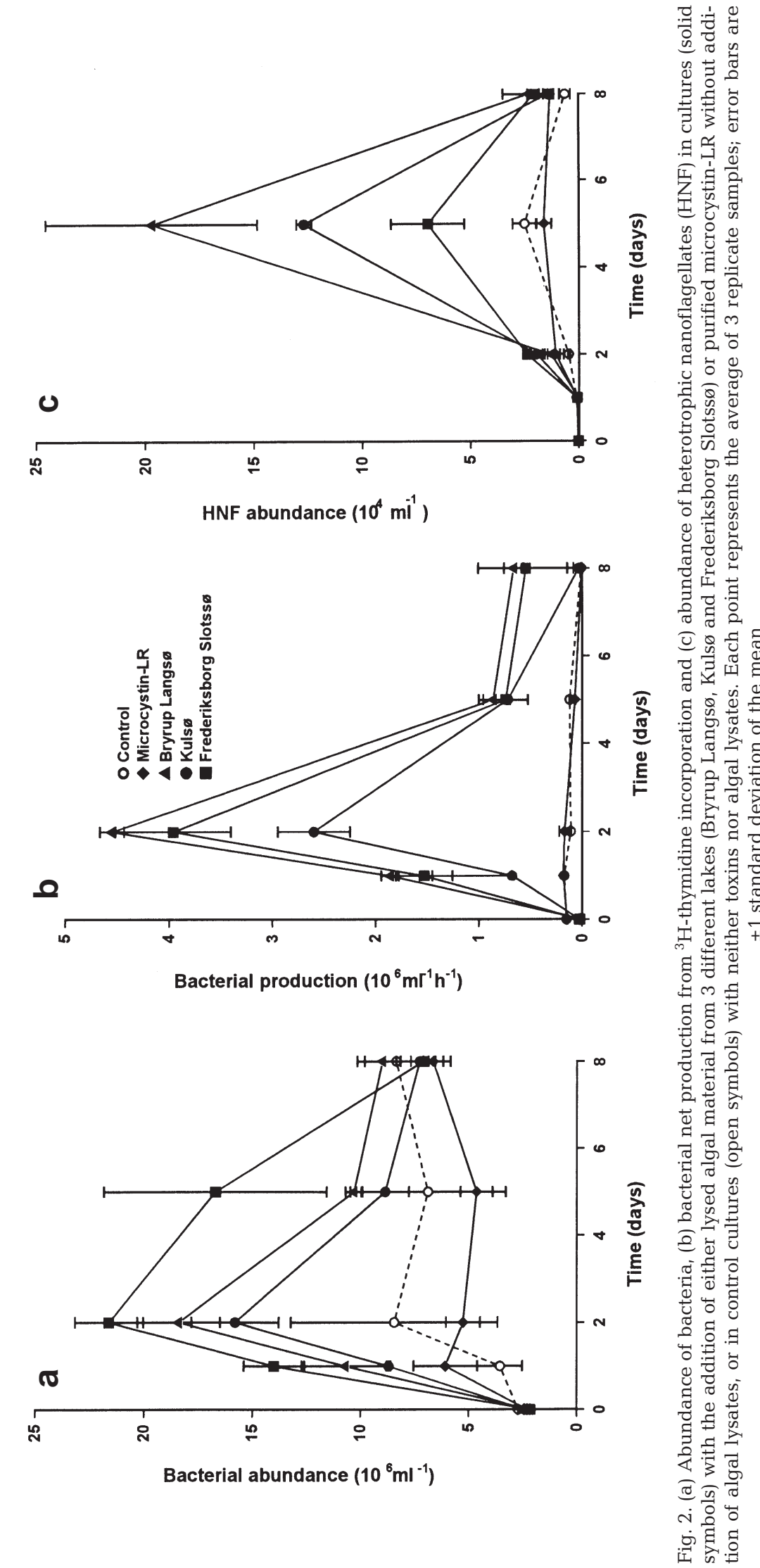
periment and averaged $12 \mathrm{mg} \mathrm{l}^{-1}$ (POC) 
a

\section{Laboratory experiment}

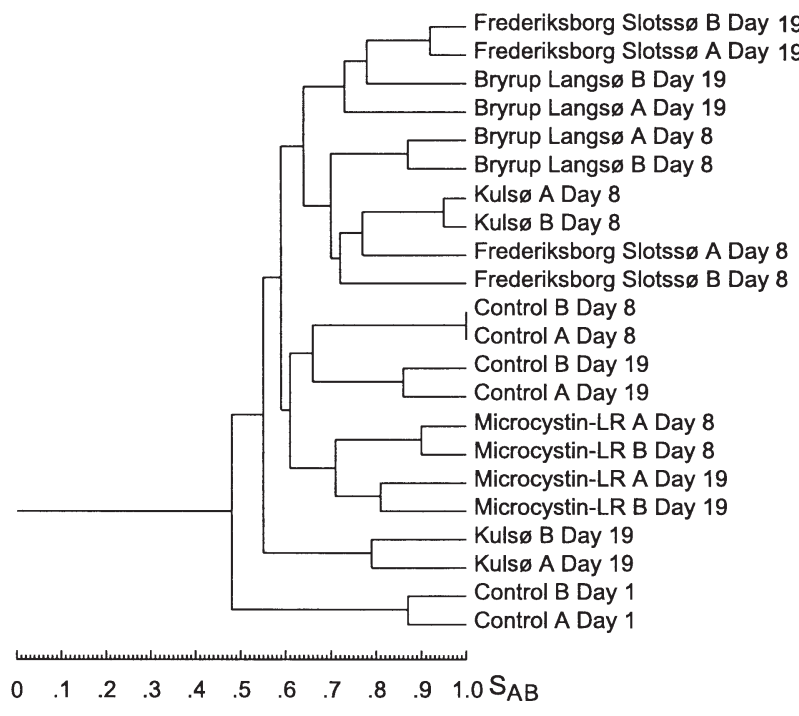

b Field experiment

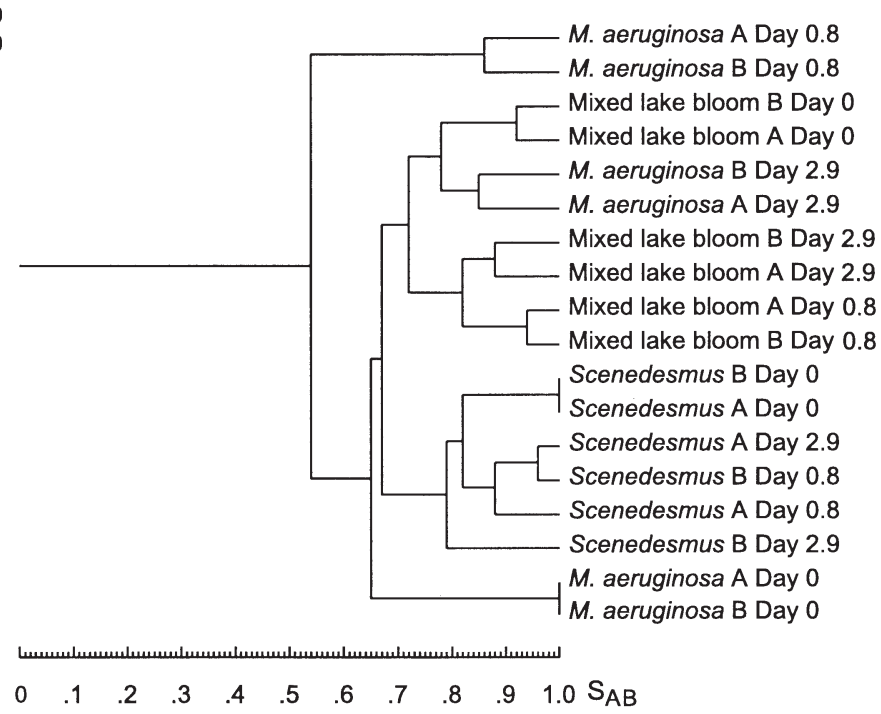

Fig. 3. Similarity of bacterial communities in the (a) laboratory and (b) field experiment based on 16S rDNA polymerase chain reaction-density gradient gel electrophoresis (PCR-DGGE) band patterns. Sample designation (S) indicates lake name, replicate (A or B) and day of sampling

and $5 \mathrm{mg} \mathrm{l}^{-1}$ (DOC), respectively. There was a significant positive linear correlation between DOC and microcystin concentrations for lysed Microcystis sp. culture $\left(\mathrm{r}^{2}=0.798, \mathrm{p}=0.001\right)$ and for lysed lake material $\left(\mathrm{r}^{2}=0.562, \mathrm{p}=0.001\right)$ but no correlation between initial DOC concentration and disappearance rates.

Bacterial abundance and production rates increased almost immediately after addition of the algal materials, especially in the treatments with material from cultured Microcystis sp., and peaked 1 to 2 d later (Fig. 4). However, both abundance and production levelled off as the DOC and POC pools were reduced. The bacterial abundances were around $2 \times 10^{7}$ cells $\mathrm{ml}^{-1}$ in all enclosures after $3 \mathrm{~d}$ but still higher than the initial abundance $\left(0.5 \times 10^{7}\right.$ cells $\left.\mathrm{ml}^{-1}\right)$. As explained for the laboratory experiment, there was agreement between the amount of DOC being degraded and the integrated bacterial carbon demand.

An increase in the abundance of HNF from $4 \times 10^{3}$ cells ml $\mathrm{ml}^{-1}$ to $3 \times 10^{4}$ to $6 \times 10^{4}$ cells $\mathrm{ml}^{-1}$ took place 2 to $3 \mathrm{~d}$ after the addition of algal materials, i.e. following the bacterial growth, but numbers of HNF were reduced when the bacterial abundance levelled off (Fig. 4).

The analysis of the genetic diversity of the bacterial communities by $16 \mathrm{~S}$ rDNA PCR-DGGE showed a temporary increase in diversity as estimated from the number of bands detected (Table 4). A total of 38 different band positions was identified, and 6 of these were common to all samples. The minimum similarity was
$54 \%$ and values between replicate microcosms agreed well (Fig. 3b). In the dendrogram all samples with Scenedesmus sp. material clustered together, as did samples with mixed lake bloom material. The samples with added Microcystis sp. culture material had lower similarities.

\section{DISCUSSION}

Despite frequent blooming and subsequent breakdown of toxic cyanobacterial blooms, it seems that concentrations of dissolved cyanobacterial toxins in natural freshwater systems are lower than can be explained by simple dilution and adsorption processes. We hypothesised that a natural bacterial community originating from a lake with cyanobacterial blooms had the potential to degrade commonly found cyanobacterial toxins (microcystins). Our laboratory and field experiments supported this.

Dilution was not a possible factor in the present study since fixed water volumes were used and no exchange of water took place. The observed disappearance of microcystin in the laboratory and field experiments progressed in a comparable way, i.e. exponentially, over 3 to $6 \mathrm{~d}$. This cannot be attributed to adsorption to particles in the water or sedimentation because POC was very low in the laboratory experiment due to pre-filtration of the water and because such processes would happen shortly after release of 
the dissolved toxin and not progressively, as observed. Likewise, the initial amount of particulate-bound microcystin recorded in the field experiment remained constant in the water over time irrespective of the different treatments. Neither of the experimental setups included sediment. Abiotic removal of microcystin through adsorption to particulate and dissolved matters seems in general to play a minor role for the removal of dissolved microcystins, as shown by Welker \& Steinberg (2000) and Morris et al. (2000). Photosensitised degradation of microcystins has been shown to occur very slowly under natural conditions (Tsuji et al. 1993, Welker \& Steinberg 2000). We assume, therefore, that the observed disappearances of microcystin were caused by a microbial degradation of microcystin. The significant correlation between DOC concentrations and dissolved microcystin concentrations in the field experiment points to a common bacterial community degrading both pools at an identical rate.

The degradation of microcystin, as well as of DOC, began almost instantaneously after addition of lysed toxic algal material to lake water with indigenous bacteria (Figs. 1 \& 4). No obvious lag phases were observed, but slow initial rates lasting approx. $1 \mathrm{~d}$ were observed in 2 of 7 cases (Bryrup Langsø, Fig. 2a and the field experiment with the mixed lake material, Fig. 4b). Neither of these cases resulted in lower degradation rates as estimated for the entire period (Table 2). Similar progression in microcystin degradation has been shown previously by Cousins et al. (1996), Rapala et al. (1994) and Lam et al. (1995). Lag phases of 3 to $9 \mathrm{~d}$ have, however, often been found (Jones \& Orr 1994, Jones et al. 1994, Lam et al. 1995, Takenaka \& Watanabe 1997, Ishi \& Abe 2000), and in several cases longer resistance (months) to degradation has also been reported (Kiviranta et al. 1991, M. F. Watanabe et al. 1992). Quantitative in-formation about the labile DOC pools are not given in these studies, but since raw extracts were used by some authors (e.g. Jones \& Orr 1994, Rapala et al. 1994, Ishi \& Abe
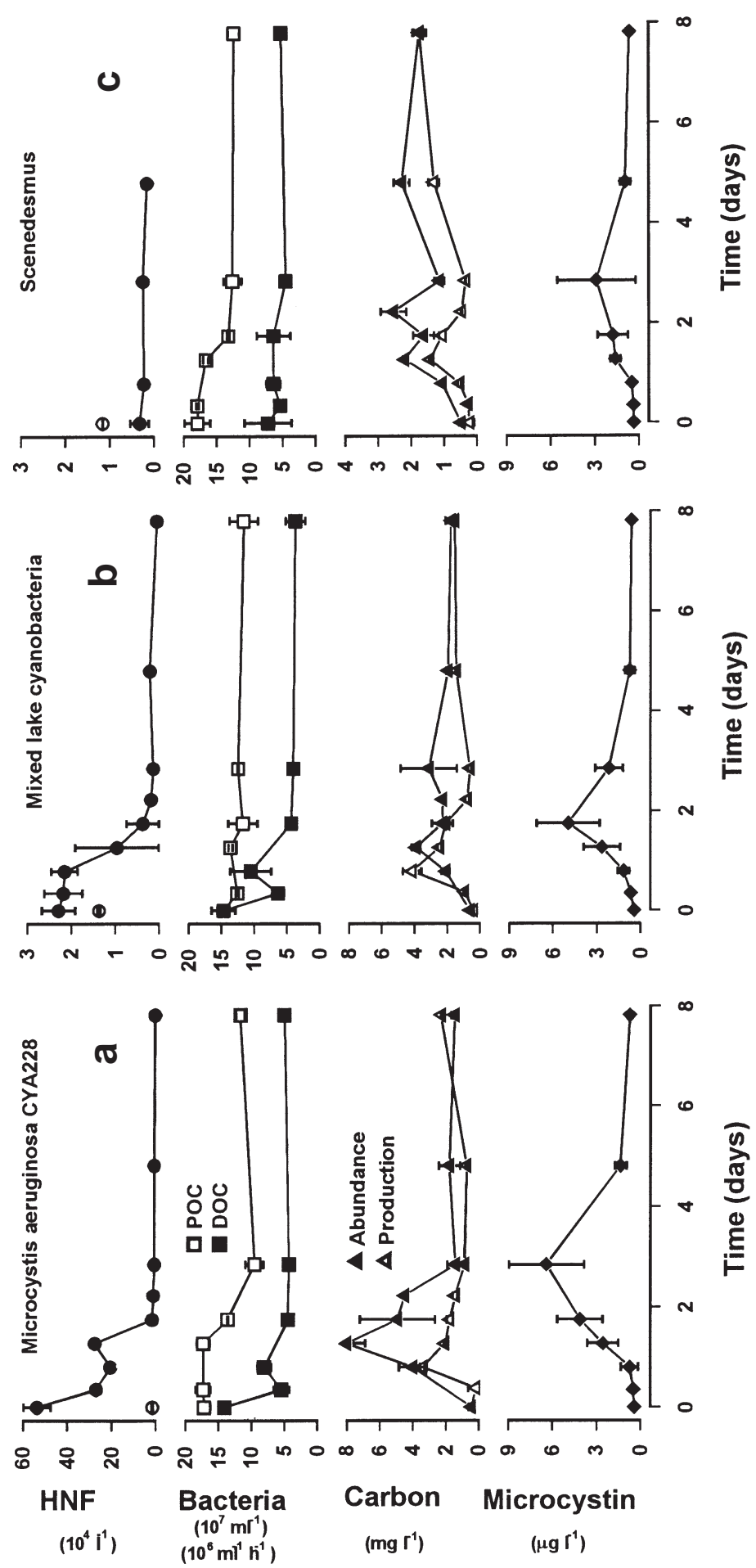
2000), it seems likely that at least some DOC was present. Bi-phasic degradation patterns including slow initial rates have been demonstrated when the start concentrations of microcystin were very high, i.e. $>1 \mathrm{mg} \mathrm{l}^{-1}$ (Jones \& Orr 1994). However, re-introduction of microcystin in the same test scenario progressed quickly and without any lag phase. No such patterns were observed in the present study.

The origin of the microbial flora and the chemicalphysical conditions during the degradation process seem to be important for an optimal degradation process. For example, Rapala et al. (1994) found that the degradation efficiency increased when the microbial inoculum originated from waters with previous cyanobacterial blooms. The degradation rates obtained in the present laboratory and field experiments were not significantly different, which may have been because all the initial bacterial cultures originated from the natural bacterial community from Frederiksborg Slotssø with frequent cyanobacterial blooms including strains that can degrade microcystin efficiently. The ability to degrade microcystin may be more widespread among naturally occurring bacteria than previously found. Despite this, only a few bacterial strains involved in the degradation of microcystin have been isolated (Jones et al. 1994, Bourne et al. 1996, Takenaka \& Watanabe 1997).

The degradation rates of microcystin in this study were between 0.485 and $1.057 \mathrm{~d}^{-1}$ (Table 2), corresponding to half-lives of around $1 \mathrm{~d}$. Somewhat slower and more variable rates and half-life times have been reported in the literature (Jones et al. 1994, Lam et al. 1995, Cousins et al. 1996, Lahti et al. 1997). The WHO recommended guideline for maximal microcystin concentration is $1 \mathrm{\mu g} \mathrm{l}^{-1}$ for drinking water resources (Chorus \& Bartram 1999), and the time required to achieve this concentration would equal between 1.3 (mixed lake material) and $7.3 \mathrm{~d}$ (Kulsø) for the natural toxic material when exposed to a bacterial community with a cyanobacterial pre-history. This means that a sudden collapse of a toxic cyanobacterial bloom in Frederiksborg Slotssø would lead to increased dissolved toxin concentrations for only short periods. A high level of dissolved toxins in the lake has been recorded only once (Christoffersen 1996), although it is not monitored routinely.

Increases in bacterial abundance and production in the laboratory and the field experiments matched the reduction in all organic compounds including the nontoxic source (Scenedesmus sp. culture) and was followed by an increase in HNFs presumably feeding on the bacteria (Figs. 2a-c \& 4, Table 3). Such sequences are typically found in situ where an algal bloom collapses (Christoffersen et al. 1990). Reductions in growth rates of a mixed population of HNFs from Fred- eriksborg Slotssø at $10 \mu \mathrm{g}$ microcystin $\mathrm{l}^{-1}$ have previously been demonstrated in laboratory and field experiments, while no effects were recorded with specific flagellate species (Christoffersen 1996). No negative effects on the proliferation of flagellates were observed in the present study, possibly because of the quick disappearance of toxins or resistance of the present flagellates to microcystin.

The observed differences in microcystin degradation rates in the present experiments (Table 2) must be due either to microcystin composition or to other compounds added along with microcystin. A relationship between the initial microcystin concentration and the degradation rates may exist at high microcystin concentrations, as reported by Jones et al. (1994), but the correlation in our study $\left(\mathrm{r}^{2}=0.192\right)$ was not significant. We expected that the degradation rates of microcystin would be accelerated by the presence of high initial pools of DOC but found no such correlations. We did, however, find significant correlations between concomitant DOC and microcystin concentrations during the field experiment, which indicates that the degradation of microcystin is proportional to the degradation of other organic substances.

The bacterial community structure changed due to the amendments with organic compounds (Fig. 3), as has been reported earlier (Fukami et al. 1985, Pinhassi et al. 1999). The diversity of the bacteria at the onset of the experiment represented by 12 to 19 band positions is comparable to reports from various other freshwater lakes (Lindstrøm 1998, Konopka et al. 1999, Casamayor et al. 2000). However, the actual number of bands observed is dependent on the conditions of the PCR and DGGE, the amount of DNA loaded on the gel, the quality and type of DNA staining, and the analysis of the gel including the human manipulation. But within the same investigation, such a comparison is justifiable. In the laboratory experiment, the bacterial diversity was analysed when most of the toxin had disappeared (after 8 and 19 d). Still, the different amendments had (or have had) an impact on the diversity of the communities, probably reflecting aftermaths of perturbations.

The number of bands increased up to a maximum of 32 in the cultures with microcystin-LR added during the incubation (Table 4). Casamayor et al. (2000) found that the bands detected by PCR-DGGE are related to bacteria accounting for more than 0.3 to $0.4 \%$ of the total bacterial community. Thus, the increase in the number of bands reflects an increase in the number of species with a higher relative abundance. The highest number of bands was found in the laboratory cultures with added microcystin-LR and in the control cultures, both after $19 \mathrm{~d}$. These cultures had the lowest concentrations of DOC and POC (Table 3), and the micro- 
cystin-LR addition developed the lowest abundance of bacteria (Fig. 2a). The higher number of bands in cultures with lower DOC and POC indicates a more diverse and oligotrophic community. The lower number of bands in cultures with a high amount of algal material added is probably due to rapid proliferation of a few fast-growing strains that can easily degrade most organic compounds along with microcystin.

The bacterial communities in the field experiment showed higher similarities within replicate microcosms than between different types of amendments, which indicates a stronger impact of the amendments on the diversity of the bacterial communities than the time course of the experiment (Fig. 3). It is unlikely, however, that bacterial changes can be explained by the presence of microcystins, as these compounds constituted little of the total amount of DOC.

\section{Implications}

The present study has shown that naturally occurring heterotrophic bacteria can degrade cyanobacterial microcystins when the bacterial community originates from a habitat where the toxins are present every year, as is the case for Frederiksborg Slotssø (Christoffersen 1996). The degradation processes were initiated at dissolved microcystin concentrations of 2 to $136 \mu \mathrm{g}$ $\mathrm{l}^{-1}$ (Figs. $1 \& 4$ ), which match those typically found under natural conditions (Chorus \& Bartram 1999). The scenario presented here explains why there have been so few reports of high concentrations of dissolved microcystins in natural waters although large and toxic blooms are frequent (Christoffersen 1996, Faster et al. 1999). When cyanobacterial bloom material collapses and the toxins are released into the water phase together with other lysate, it quickly stimulates growth of bacterial strains capable of degrading the dissolved substrates. Around $90 \%$ of the initial amount of microcystin disappeared from the water phase within $5 \mathrm{~d}$ irrespective of the starting concentration. It implies that dissolved toxins are not likely to accumulate under natural conditions at sites where cyanobacteria are common (Lahti et al. 1997).

There might, however, be several explanations regarding why an initial lag phase in microcystin degradation can occur, as has been found by others. One such factor may be a correlation of the initial microcystin concentration and the degradation rate, as suggested by Jones \& Orr (1994), although this was not evident from the present study using a low initial microcystin concentration. A minimum microcystin concentration may, however, be needed to induce diversity changes in the bacterial community. Another factor may be the presence of a labile carbon pool since it accelerates both DOC and microcystin degradation, as illustrated by the close relationship observed during the field experiment.

Thus, our study confirms that bacteria can efficiently degrade microcystins in natural waters with a previous cyanobacterial history, which implies that bacterial strains specific for such activities are present. From the present laboratory and field experiments, it seems that when microcystins are released suddenly from cyanobacterial cells to the water column of an eutrophic lake, their half-life times are around $1 \mathrm{~d}$ and the microcystins are further degraded to insignificant levels, i.e. below the recommended concentration for drinking water of $1 \mathrm{\mu g} \mathrm{l}^{-1}$ (Chorus \& Bartram 1999) within approx. $8 \mathrm{~d}$. Overall, these findings are important to consider when evaluating the fate of microcystins in freshwater ecosystems, as the toxins are known to have negative effects on other parts of the aquatic ecosystem (Lindholm et al. 1992) and to humans using natural waters.

Acknowledgements. We wish to thank the National Science Research Council for financial support (contract no. 9502725). Nils Willumsen, Shazia Rafig and Tina Thane provided valuable technical assistance.

\section{LITERATURE CITED}

Berg K, Skulberg OM, Skulberg R (1987) Effects of decaying toxic blue-green algae on water quality: a laboratory study. Arch Hydrobiol 108:549-563

Bourne DG, Jones GJ, Blakeley RL, Jones A, Negri AP, Riddles P (1996) Enzymatic pathway for the bacterial degradation of the cyanobacterial cyclic peptide toxin microcystin LR. Appl Environ Microbiol 62:4086-4094

Carmichael WW (1992) Cyanobacteria secondary metabolites: the cytotoxins. J Appl Bacteriol 72:445-459

Casamayor EO, Schäfer H, Baneras L, Pedós-Alió C, Muyzer G (2000) Identification of and spatio-temporal differences between microbial assemblages from two neighbouring sulphureous lakes: comparison by microscopy and denaturing gradient gel electrophoresis. Appl Environ Microbiol 66:499-508

Chorus I, Bartram J (1999) Toxic cyanobacteria in water. A guide to their public health consequences, monitoring and management. E \& FN Spon, London

Christoffersen K (1996) Ecological implications of cyanobacterial toxins in aquatic food webs. Phycologia 35(6 Suppl): $42-50$

Christoffersen K, Riemann B, Hansen LR, Klysner A, Sørensen HB (1990) Qualitative importance of the microbial loop and plankton community structure in a eutrophic lake during a bloom of cyanobacteria. Microb Ecol 20: 253-272

Chu FS, Huang X, Wei RD, Carmichael WW (1989) Production and characterization of antibodies against microcystins. Appl Environ Microbiol 655:1928-1933

Cousins IT, Bealing DJ, James HA, Sutton A (1996) Biodegradation of microcystin-LR by indigenous mixed bacterial populations. Water Res 30:481-485

Donati CM, Drikas M, Hayes R, Newcombe G (1994) Micro- 
cystin-LR adsorption by powdered activated carbon. Water Res 28:1735-1742

Falconer I (1993) Mechanism of toxicity of cyclic peptide toxins from blue-green algae. In: Falconer I (ed) Algal toxins in seafood and drinking water. Academic Press, New York, p 177-187

Faster J, Neumann U, Wirsing B, Weckesser J, and 3 others (1999) Microcystins (hepatotoxic heptapeptides) in German freshwater bodies. Environ Toxicol 14:13-23

Feitz AJ, Waite TD, Jones GJ, Boyden BH, Orr PT (1999) Photocatalytic degradation of the blue green algal toxin microcystin-LR in a natural organic-aqueous matrix. Environ Sci Technol 33:243-249

Fuhrman JA, Azam F (1980) Bacterioplankton secondary production estimates for coastal waters of British Colombia, Antarctica and California. Appl Environ Microbiol 39: 1085-1095

Fukami K, Simidu U, Taga N (1985) Microbial decomposition of phyto- and zooplankton in seawater. II. Changes in the bacterial community. Mar Ecol Prog Ser 21:7-13

Heuer H, Krsek M, Baker P, Small K, Wellington EMH (1997) Analysis of actinomycete communities by specific amplification of genes encoding 16S rRNA and gel-electrophoretic separation in denaturing gradients. Appl Environ Microbiol 63:3233-3241

Heuer H, Angolan B, Smalla K (1998) Application of temperature gradient gel electrophoresis (TGGE) to study microbial communities. Workshop on Genetic Fingerprinting of Microbial Communities: present status and future perspectives. Max-Planck-Institute for Marine Microbiology, Bremen

Ishi H, Abe A (2000) Release and biogradation of microcystins in blue-green algae, Microcystis PCC7820. J Sch Mar Sci Technol Tokai Univ 49:143-157

Jones GJ, Orr PT (1994) Release and degradation of microcystin following algicide treatment of a Microcystis aeruginosa bloom in a recreational lake, as determined by HPLC and protein phosphatase inhibition assay. Water Res 28:871-876

Jones GJ, Bourne DG, Blakeley RL, Doelle H (1994) Degradation of the cyanobacterial hepatotoxin microcystin by aquatic bacteria. Nat Toxins 2:228-235

Kiviranta J, Sivonen K, Lahti K, Luukkainen R, Niemelä SI (1991) Production and biodegradation of cyanobacterial toxins: a laboratory study. Arch Hydrobiol 121:281-294

Konopka A, Bercot T, Nakatsu C (1999) Bacterioplankton community diversity in a series of thermally stratified lakes. Microb Ecol 38:126-135

Lahti K, Rapala J, Färdig M, Niemelä M, Sivonen K (1997) Persistence of cyanobacterial hepatotoxin, microcystin-LR in particulate material and dissolved in lake water. Water Res 31:1005-1012

Lam AKY, Prepas EE (1997) In situ evaluation of options for chemical treatment of hepatotoxic cyanobacterial blooms. Can J Fish Aquat Sci 54:1736-1742

Lam AKY, Fedorak PM, Prepas EE (1995) Biotransformation of the cyanobacterial hepatotoxin microcystin-LR, as determined by HPLC and protein phosphatase bioassay. Environ Sci Technol 28:242-246

Lambert TW, Holmes CFB, Hrudey SE (1996) Adsorption of microcystin-LR by activated carbon and removal in full scale water treatment. Water Res 30:1411-1422

Lawton LA, Robertson PKJ, Cornish BJP, Jaspars M (1999) Detoxification of microcystins (cyanobacteria hepatotoxins) using $\mathrm{TiO}^{2}$ photocatalytic oxidation. Environ Sci Tech- nol 33:771-775

Lindholm T, Eriksson JE, Reinikainen M (1992) Ecological effects of toxic cyanobacteria. Environ Toxicol Water Qual $7: 87-93$

Lindstrøm ES (1998) Bacterioplankton community composition in a boreal forest lake. FEMS Microbiol Ecol 27: 163-174

Lyck $\mathrm{S}$ (in press) Inverse relationship between quota and growth rate in batch cultures of Microcystis aeruginosa. Limnol Oceanogr

Lyck S, Gjølme N, Utkilen H (1996) Iron starvation increases toxicity of Microcystis aeruginosa CYA 228/1 (Chroococcales, Cyanophyceae). Phycologia 35(Suppl):120-124

Morris RJ, Williams DE, Luu HA, Holmes CFB, Andersen RJ, Calvert SE (2000) The adsorption of microcystin-LR by natural clay particles. Toxicon 38:303-308

Nicholson BC, Rositano J, Burch MD (1994) Destruction of cyanobacterial peptide hepatoxins by chlorine and chloramine. Water Res 28:1297-1303

Pinhassi J, Azam F, Hemphälä J, Long RA, and 3 others (1999) Coupling between bacterioplankton species composition, population dynamics, and organic matter degradation. Aquat Microb Ecol 17:13-26

Rapala J, Lahti K, Sivonen K, Niemelä SI (1994) Biodegradability and absorption on lake sediments of cyanobacterial hepatotoxins and anatoxin-a. Lett Appl Microbiol 19: 423-426

Riemann L, Winding A (2001) Community dynamics of freeliving and particle-associated bacterial assemblages during a freshwater phytoplankton bloom. Microb Ecol 42: 274-285

Robertson PKJ, Lawton LA, Comish BJPA, Jaspars C (1998) Processes influencing the destruction of microcystin-LR by $\mathrm{TiO}_{2}$ photocatalysis. J Photochem Photobiol 116:215-219

Sambrook J, Fritsch E, Maniatis T (1989) Molecular cloning. A laboratory manual. Cold Spring Harbor Laboratory, Cold Spring Harbor

Skulberg OM, Carmichael WW, Codd GA, Skulberg R (1994) Taxonomy of toxic cyanophyceae (cyanobacteria). In: Falconer (ed) Algal toxins in seafood and drinking water. Academic Press, New York, p 177-187

Smits JD, Riemann B (1988) Calculation of cell production from ${ }^{3} \mathrm{H}$-thymidine incorporation with freshwater bacteria. Appl Environ Microbiol 54:2213-2219

Takenaka S, Watanabe MF (1997) Microcystin-LR degradation by Pseudomonas aeruginosa alkaline protease. Chemosphere 34:749-757

Thostrup L, Christoffersen K (1999) Accumulation of microcystin in Daphnia magna feeding on toxic Microcystis. Arch Hydrobiol 145:447-467

Tsuji K, Naito NS, Kondo F, Ishihawa N, and 3 others (1993) Stability of microcystins from cyanobacteria: effects of light on decomposition and isomerization. Environ Sci Technol 28:173-177

Watanabe MF, Tsuji K, Watanabe Y, Harada KI, Suzuki M (1992) Release of heptapeptide toxin (microcystin) during decomposition process of Microcystis aeruginosa. Nat Toxins 1:48-53

Watanabe MM, Kaya M, Takamura N (1992) Fate of toxic cyclic hepatapeptides, the microcystins, from blooms of Microcystis (Cyanobacteria) in a hypertrophic lake. J Phycol 28:761-767

Welker M, Steinberg C (2000) Indirect photolysis of cyanotaoxins: one possible mechanism for their low persistence. Water Res 33:1159-1164 